\title{
Genetic diversity and structure of the critically endangered Artocarpus annulatus, a crop wild relative of jackfruit ( $A$. heterophyllus)
}

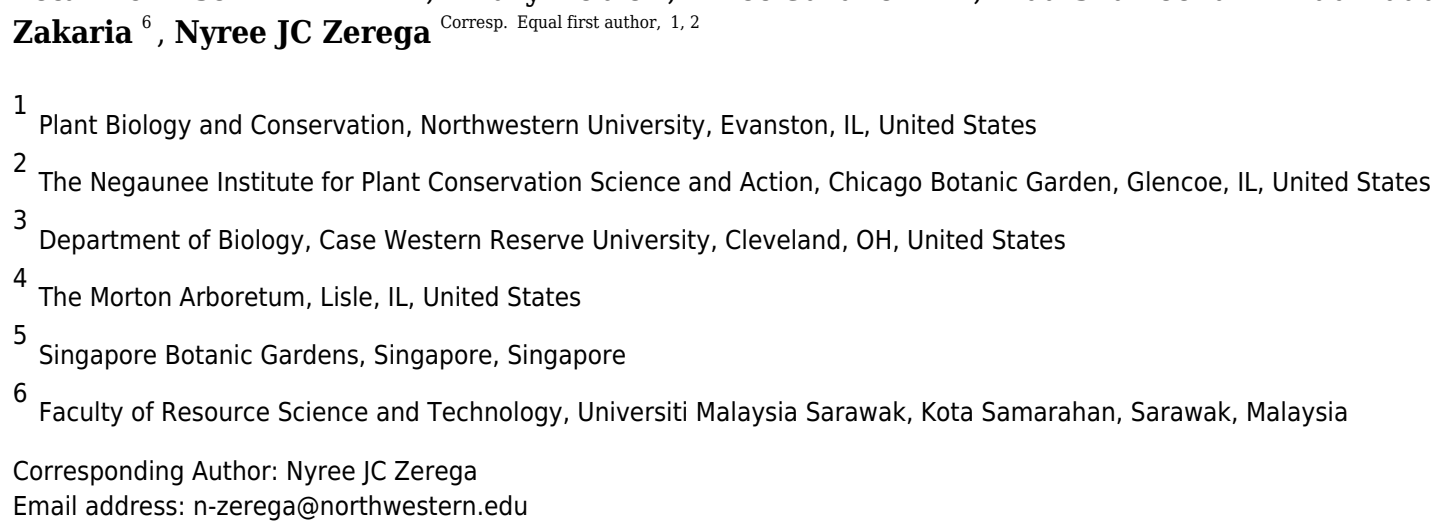

Limestone karsts of Southeast Asia can harbor high levels of endemism, but are highly fragmented, increasingly threatened, and their biodiversity is often poorly studied. This is true of the Padawan Limestone Area of Sarawak, Malaysia, home to the endemicArtocarpus annulatus, the closest known wild relative of two important and underutilized fruit tree crops, jackfruit ( $A$. heterophyllus) and cempedak ( $A$. integer). Identifying and conserving crop wild relatives is critical for the conservation of crop genetic diversity and breeding. In 2016 and 2017, five A. annulatus populations were located, and leaf material, locality information, and demographic data were collected. Microsatellite markers were used to assess genetic diversity and structure among populations, and to compare levels of genetic diversity to closely related congeneric species. Results indicate no evidence of inbreeding in $A$. annulatus, and there is no genetic structure among the five populations. However, diversity measures trended lower in seedlings compared to mature trees, suggesting allelic diversity may be under threat in the youngest generation of plants. Also, genetic diversity is lower in A. annulatus compared to closely related congeners. The present study provides a baseline estimate of $A$. annulatus genetic diversity that can be used for comparison in future studies and to other species in the unique limestone karst ecosystems. Considerations for in situ and ex situ conservation approaches are discussed. 
2 Genetic diversity and structure of the critically endangered Artocarpus annulatus, a crop

3 wild relative of jackfruit ( $A$. heterophyllus)

4

5

6

8

Leta Dickinson $^{1, \text { Equal first author, Hilary Noble }}{ }^{2}$, Elliot M. Gardner ${ }^{3,4,5}$, Aida S.A. Puad ${ }^{6}$, W.N.F. Wan Zakaria ${ }^{6}$, Nyree J.C. Zerega ${ }^{1,2, \text { Equal first author }}$

${ }^{1}$ Northwestern University, Plant Biology and Conservation, Evanston, IL, USA

${ }^{2}$ Chicago Botanic Garden, The Negaunee Institute for Plant Conservation Science and Action, Glencoe, IL, USA

${ }^{3}$ The Morton Arboretum, Lisle, Illinois, USA

${ }^{4}$ Case Western Reserve University, Department of Biology, Cleveland, Ohio, USA

${ }^{5}$ Singapore Botanic Gardens, Singapore, Singapore

${ }^{6}$ Faculty of Resource Science and Technology, Universiti Malaysia Sarawak, Kota Samarahan, Sarawak, Malaysia

Corresponding Author:

Nyree J.C. Zerega

Email address: n-zerega@northwestern.edu

\section{Abstract}

Limestone karsts of Southeast Asia can harbor high levels of endemism, but are highly

fragmented, increasingly threatened, and their biodiversity is often poorly studied. This is true of the Padawan Limestone Area of Sarawak, Malaysia, home to the endemic Artocarpus annulatus, the closest known wild relative of two important and underutilized fruit tree crops, jackfruit ( $A$. heterophyllus) and cempedak (A. integer). Identifying and conserving crop wild relatives is critical for the conservation of crop genetic diversity and breeding. In 2016 and 2017, five $A$. annulatus populations were located, and leaf material, locality information, and demographic data were collected. Microsatellite markers were used to assess genetic diversity and structure among populations, and to compare levels of genetic diversity to closely related congeneric species. Results indicate no evidence of inbreeding in A. annulatus, and there is no genetic structure among the five populations. However, diversity measures trended lower in seedlings 
35

36

37

compared to mature trees, suggesting allelic diversity may be under threat in the youngest generation of plants. Also, genetic diversity is lower in A. annulatus compared to closely related congeners. The present study provides a baseline estimate of $A$. annulatus genetic diversity that can be used for comparison in future studies and to other species in the unique limestone karst ecosystems. Considerations for in situ and ex situ conservation approaches are discussed.

\section{Introduction}

The karst limestone formations of Southeast Asia are dramatic, rugged landscapes that are home to some of the most unique and understudied flora and fauna in the world (Tuyet 2001; Clements et al. 2006; Chung et al. 2014; Hughes 2017). There are approximately $800,000 \mathrm{~km}^{2}$ of karst ecosystems in tropical Southeast Asia and southern China, and they include several UNESCO World Heritage sites (Day and Urich 2000; Williams 2008). Most karsts were formed millions of years ago by calcium-secreting marine organisms, and the current landscapes are the result of geomorphological processes that have formed complex terrains such as fissured and precipitous cliffs, jagged towers, sinkholes, extensive cave systems, and subterranean rivers, harboring a range of ecological niches (Clements et al. 2006; Williams 2008). The resulting landscapes are naturally fragmented mosaics of karst and ordinary terrain, promoting edaphic isolation and high levels of endemism (Kruckeberg and Rabinowitz 1985; Farjon et al. 2002; Schilthuizen 2004; Musser et al. 2005; Williams 2008). Healthy karst habitats provide tangible benefits to humans, such as water from below-ground aquifers, as well as a range of ecosystem services (Beynan 2011), some of which are due to their unique biodiversity (Schilthuizen 2004; Clements et al. 2006). However, due to human practices, the karst ecosystems and the species inhabiting them are themselves increasingly at risk of further fragmentation and degradation (Clements et al. 2006, Clements et al. 2008, Struebig et al. 2009, Latinne et al. 2011, Hughes et al. 2017). The 
59

60

61

62

63

64

65

66

67

68

69

70

71

72

73

74

75

76 77 of $32 \mathrm{~km}^{2}$.

78

79

80

81

most immediate and direct threat is overexploitation of resource extraction, especially limestone and mineral mining (Kiew et al. 2017; Beynan 2011, Hughes et al. 2017). These extremely lucrative but destructive extractive practices can have cascading effects of severe fragmentation and habitat degradation, leading to serious negative impacts on flora, fauna, and humans.

In Sarawak, Malaysia, the Padawan limestone formation (in the southwest part of Kuching Division) is the largest and one of the oldest (dating from about 163 to 100 million years ago) outcrops among the six limestone biodistricts there (Lim 2008) (Cranbrook 2004). One of the species endemic to this habitat is the critically endangered tree, Artocarpus annulatus Jarrett, known only from the Padawan-Serian-Tebedu karst forests (Fig. 1). This species is a member of the mulberry (Moraceae) family and the closest wild relative of the important tropical food crops jackfruit (A. heterophyllus Lam.) and cempedak (A. integer (Thunb.) Merr.) (Zerega et al. 2010; Williams et al. 2017, Zerega et al. 2019). Artocarpus annulatus was first described nearly 45 years ago (Jarrett 1975) but remains poorly understood in terms of its biology and distribution. As of 2015, the species was known from only nine herbarium specimens. They were all collected between 1960-1999 and came from just four limestone hill forest outcrops within the PadawanSerian-Tebedu limestone karst formation in Kuching (Gunung Mentawa, Gunung Gayu, and Gunung Teng Bukap) and Serian (Gunung Payang) Divisions (Fig. 2). According to Zerega et al. (2019), there are thought to be fewer than 50 mature individuals in an area of occupancy (AOO)

The importance of studying and conserving A. annulatus has broad implications beyond karst systems, as the genetic diversity of crop wild relatives can prove a useful source of novel traits (Lobell et al. 2008). The economic and food value of its cultivated close relatives, cempedak and jackfruit, are likely to increase, as they grow in tropical regions where food insecurity is high, 
82 and provide greater local autonomy in food production systems (Ford-Lloyd 2011; Jones et al.

83 2011, Wang et al. 2018, Witehrup et al. 2019). As agriculture adapts to climate change, long-

84 lived tree crops may play an increasingly important role in the global diet. It is known that

85 jackfruit and cempedak are interfertile, because hybrid cultivars exist (Wang et al. 2018). Given

86 that $A$. annulatus is the only other member of the lineage including jackfruit and cempedak

87 (Williams et al. 2017), it is possible that they could all be interfertile and traditional plant

88 breeding could incorporate desirable traits, such as expanding the edaphic conditions of the crop 89 species.

90 Depending on what we know about the genetic diversity and structure of endangered species, 91 different approaches to conservation may be warranted (Widener and Fant 2018, Münzbergová 92 2005, Crozier 1997). Due to the unique karst environment, it is possible that A. annulatus 93 populations have long been isolated and small. However, human-caused fragmentation may have 94 further reduced genetic diversity, making it harder for the species to rebound and recover (Leimu 95 et al. 2006). While there are limited studies examining population genetics of endangered flora in 96 limestone karst systems of Southeast Asia, the unique habitat and fragmented nature of karst 97 systems have made them of interest for understanding species diversification through isolation.

98 Recent studies of common karst endemic plant genera (Begonia and Primulina) found substantial 99 differentiation and significant isolation by distance across populations (Gao et al. 2015, Tseng et 100 al. 2019). Understanding genetic patterns and diversity in A. annulatus is an important step 101 towards developing conservation strategies for this crop wild relative. This study uses 102 microsatellite and demographic data to assess the genetic diversity and structure of A. annulatus, 103 an endemic tree of the Padawan-Serian-Tebedu karst forests of Sarawak, Malaysia. Comparisons 104 of genetic diversity are also made to its two closest relatives, which are commonly occurring 
105 underutilized crops. Specifically, we test the following hypotheses: Given the relatively recent

106 (in decades) destruction of $A$. annulatus habitat, the known populations of $A$. annulatus will

107 show recent evidence of gene flow and as there will not be population specific alleles; due to

108 pressures of increased fragmentation and habitat loss, recruitment of younger individuals may be

109 more tenuous and lead to decreased genetic diversity in younger individuals compared to mature

110 trees; and as a critically endangered species with restricted distribution, A. annulatus will harbor

111 less genetic diversity than its widely distributed congeners. It is hoped that the results can inform

112 management plans for in situ and ex situ conservation efforts and provide much needed

113 information about the unique biota of the Southeast Asian karst formations. Understanding how

114 diversity is distributed among populations will provide insight into the importance of whether in

115 situ or ex situ conservation efforts should be targeted toward all or some populations to capture

116 the existing diversity of this critically endangered species.

118 Materials \& Methods

119 Species information

120 Artocarpus annulatus is a small to mid-sized evergreen tree, growing up to $10 \mathrm{~m}$ tall on karst

121 outcrops in Sarawak, Malaysia. It is monoecious, with separate male and female inflorescences

122 occurring on the same individual tree. The male inflorescences have rings around them, for

123 which the specific epithet "annulatus" is named (Fig. 1). Once fertilized, the female

124 inflorescence develops into a multiple fruit structure (called a syncarp) that is cauliflorous (i.e.

125 grows directly from the tree trunk) (Fig. 1). Like all members of the genus Artocarpus, it

126 produces copious white exudate from all parts when cut. The closest relatives of $A$. annulatus are

127 two important crop species: A. heterophyllus (jackfruit) and A. integer (cempedak). They also 
128 bear cauliflorous fruit structures, which are edible and much larger than A. annulatus (reaching

129 up to $45 \mathrm{~kg}$ in A. heterophyllus). Jackfruit is thought to be native to the western Ghats of India

130 (with a possible secondary center of diversity in Bangladesh) (Witherup et al. 2019). It is grown

131 throughout much of the tropics today. Cempedak (A. integer var. integer) is thought to be native

132 to peninsular Malaysia and possibly Borneo; bangkong (A. integer var. silvestris) is a close wild

133 relative native to peninsular Malaysia (Wang et al. 2018).

\section{Site information}

135 Artocarpus annulatus is known only from the Padawan limestone area in Kuching District,

136 Sarawak, Malaysia (Fig. 2). This area consists of small mountains with tower karst formations.

137 The landscape is dominated by very steep, or even vertical sided limestone "towers," known as

138 tower karst formations. It is the result of once continuous limestone rock being eroded (Brenda et

139 al, 2004), The towers are sculptured by chemical and mechanical processes forming a terrain

140 covered by jagged pinnacles and deep pits and crevices. Artocarpus annulatus can be found at

141 the base of the karst forest mountains on relatively flat ground, as well as at higher elevations

142 among the karst towers and growing sideways from outcrops, with roots clinging to the limetone

$143 \operatorname{rock}($ Fig. 1).

144 Sampling

145 In 2016 and 2017, fieldwork was undertaken in the Padawan-Serian-Tebedu karst limestone

146 forests in Sarawak, Malaysia for collection and observation of A. annulatus (Zerega et al. 2019).

147 Research permits were approved by the Ibu Pejabat Jabatan Hutan Wisma Sumber Alam

148 (National Parks and Nature Reserves, Forest Department), Sarawak for 2016 (Permit no.

149 NCCD.907.4.4(JLD.13)-195) and renewed for 2017 (Permit no. NPW.907.4.4(JLD.14)-137). All

150 known sites from which $A$. annulatus had previously been recorded (Gunung Gayu, Gunung 
151 Mentawa, Gunung Teng Bukap, and Gunung Payang), as well as four additional sites in

152 surrounding areas of limestone hill forest (Gunung Manok, Gunung Bedoh, Gunung Jambusan,

153 and Fairy Caves) were visited to search for A. annulatus individuals (Zerega et al. 2019).

154 Individuals of $A$. annulatus were found in five sites (Gunung Mentawa, Gunung Gayu, Gunung

155 Teng Bukap, Gunung Manok, and Gunung Bedoh) (Fig. 2). Representative collections were

156 made at each site, and the number and age class of individuals from each population varied

157 (Table S1). At one of the sites where collections had previously been made in 1999 (Gunung

158 Payang), the area was found in 2017 to have a small area of limestone hill forest remaining, and

159 a nearby rubber plantation. However, no A. annulatus was found (pers. obs. Zakaria). For all

160 sites where $A$. annulatus was found, GPS coordinates, images, and herbarium collections were

161 taken for representative samples. In addition, leaf tissue samples (dried in silica), for $131 \mathrm{~A}$

162 annulatus trees were taken across the five sites (Table S1). For most of these 131 trees, diameter

163 at breast height ( $\mathrm{dbh}$ ) measurements, and notes about the age class of the samples were also

164 taken. The trees sampled were of varying maturity (seedling, sapling, and reproductively

165 mature). Seedlings were defined as having a height less than 1 meter, while mature plants were

166 defined as having a dbh of $5.5 \mathrm{~cm}$ or more, because plants that met this criterion showed signs of

167 past reproduction. Anything taller than 1 meter and with a dbh less than $5.5 \mathrm{~cm}$ was considered a

168 sapling. The dried leaf material was shipped to the Chicago Botanic Garden where it was stored

169 at $-20^{\circ} \mathrm{C}$. Addititional data for comparison to closely related congeners of $A$. annulatus came

170 from jackfruit (A. heterophyllus, Witherup et al. 2019, n=373 from Bangladesh; and Melhem

$1712015, \mathrm{n}=373$ from India), cempedak (A. integer var. integer, $\mathrm{n}=344)$, and $A$. integer var. silvestris

172 ( $\mathrm{n}=187$, bangkong, a wild relative of cempedak) (Wang et al. 2018).

\section{Genetic data collection}


174 Genomic DNA was extracted from $1 \mathrm{~cm}^{2}$ dried leaf using either the Qiagen DNeasy kits (Hilden,

175 Germany) following standard protocol or a modified cetyltrimethylammonium bromide (CTAB)

176 method (Doyle and Doyle 1987). Nine different microsatellite primers developed for $A$. altilis

177 (Witherup et al. 2013) were used following the methods of Witherup et al. (2013). These loci

178 previously revealed diversity in the two most closely relatives of A. annulatus: jackfruit (A.

179 heterophyllus) and cempedak (A. integer) (Wang et al. 2018, Witherup et al. 2019). The

180 microsatellite regions amplified in this study were all dinucleotide repeats: MAA26 (black D2

181 dye), MAA54 (blue D4 dye), MAA105 (black D2 dye), MAA122 (green D3 dye), MAA140

182 (blue D4 dye), MAA156 (green D3 dye), MAA182 (blue D4 dye), MAA178 (green D3 dye), and

183 MAA196 (black D2 dye). The forward primers were labelled with WellRed fluorescent dyes,

184 shown in parentheses above.

185 The PCR reactions contained $5 \mu \mathrm{L}$ of $2 \mathrm{x}$ myTaq Mix (Bioline, Taunton, Massachusetts,

$186 \mathrm{USA}$ ), $0.15 \mu \mathrm{L} 20 \mathrm{mg} / \mathrm{ml}$ BSA (bovine serum albumin), $0.25 \mu \mathrm{L}$ each of labelled forward and 187 reverse primers (10 $\mu$ m concentration), $3.35 \mu \mathrm{L}$ of DNA-free water, and $1 \mu \mathrm{L}$ of DNA (with

188 concentrations between 10 and $80 \mathrm{ng} / \mu \mathrm{L})$. The PCR cycles were: 2 minutes at $94^{\circ} \mathrm{C}$ for initial 189 denaturization, followed by 34 cycles of $94^{\circ} \mathrm{C}$ for 30 seconds of denaturation, $52^{\circ} \mathrm{C}$ for 1 minute 190 of annealing, then $72^{\circ} \mathrm{C}$ for 2 minutes of extension; the 34 cycles were then followed by $72^{\circ} \mathrm{C}$ for 19110 minutes of final extension (Wang et al. 2018).

192 The PCR products were run on a Beckman Coulter CEQ 8000 Genetic Analysis System 193 (Beckman Coulter, Brea, CA) following the methods of Witherup et al. (2013) and multiplexed 194 via the same groupings of Wang et al. (2018). The samples were scored alongside a GenomeLab $195400 \mathrm{bp}$ internal size standard ladder that was added to HiDi formamide (20 $\mu \mathrm{L}$ ladder per $1.5 \mathrm{~mL}$ 196 of HiDi) (Azco Biotech., San Diego, CA, USA). In each well, $30 \mu \mathrm{L}$ of the HiDi /ladder mixture 
197 were added to between 1.0 and $2.0 \mu \mathrm{L}$ of PCR product, depending on the strength of the

198 fluorescence color. These concentrations were determined by running a few different

199 combinations and dilutions of primers and determining which resulted in the clearest peaks.

200 The resulting peaks were scored manually using Beckman Coulter CEQ 8000 Software 9.0.

201 Allele sizes are recorded based on the size of the ladder and electrophoresis rates as described in

202 Wang et al. (2018). Artocarpus annulatus is thought to be functionally diploid, and as such each 203 region should display either one (homozygous) or two (heterozygous) alleles. Previous studies 204 have revealed that some primers (including primers MAA196 and MAA156) may amplify two 205 regions, and up to four alleles can be present (Wang et al. 2018; Witherup et al. 2013; Witherup 206 et al. 2019). This was rarely observed in A. annulatus. In a few samples when more than three 207 strong peaks were observed, the rarest allele was omitted (allele size 268 for primer MAA196; 208 allele size 170 for primer MAA54) (Wang et al. 2018).

\section{Analysis of genetic data}

210 Microchecker analysis (Van Oosterhout et al. 2004), using the Oosterhout method was run to 211 check for null alleles. The microsatellite data were analyzed using GenAlEx v.6.5 (Peakall and 212 Smouse 2012) to calculate diversity measures, including average number of alleles per locus $213\left(\mathrm{~N}_{\mathrm{a}}\right)$, number of effective alleles $\left(\mathrm{N}_{\mathrm{e}}\right)$, observed and expected heterozygosities $\left(H_{\mathrm{o}}\right.$ and $\left.H_{\mathrm{e}}\right)$, 214 number of private alleles $\left(\mathrm{P}_{\mathrm{a}}\right)$, inbreeding coefficient $\left(F_{\mathrm{IS}}\right)$ and fixation index $\left(F_{\mathrm{ST}}\right)$. Allelic 215 richness was calculated in the R package Hierfstat (Goudet 2005). To test if diversity measures 216 were significantly different across populations and age classes, single factor ANOVAs were 217 conducted in Excel v. 16.16.14.

218 Genetic structure among populations was visualized using STRUCTURE v.2.3.4 (Pritchard, 219 Stephens, and Donnelly 2000). Twenty independent runs per $K$ were carried out with a burn-in 
220 period of 10,000 and 10,000 MCMC iterations for $K=1-20$. Structure Harvester (Earl and

221 vonHoldt 2012) was used to determine the most likely value of genetic clusters $(K)$

222 implementing the Evanno method (Evanno et al. 2005). Spatial clustering of populations was

223 assessed using Principle Coordinate Analysis (PCoA) of Nei's genetic distance in GeneAlEx

224 (Peakall and Smouse 2012). Additionally, GEneAlEx v.6.5 (Peakall and Smouse 2012) was used

225 to assess genetic differentiation among populations AMOVA. To assess whether there was any

226 genetic differentiation among age classes, $\mathrm{PCoA}, F_{\mathrm{ST}}$, and AMOVA analyses were also run for

227 the three age classes in GeneAlEx v.6.5 (Peakall and Smouse 2012). For PCoA, the two principle

228 coordinates were plotted with 95\% confidence ellipse in R (ggplot) (Wickham 2016).

\section{Results}

\section{Microsatellite loci}

231 Of the nine different microsatellite primers that were tested, one (MAA178) consistently

232 amplified two readily distinguishable regions, which were scored as separate loci and

233 differentiated as primer MAA178A and primer MAA178B (following Wang et al. 2018). Across

234 the resulting 10 loci, there were 44 detected alleles, however, two loci were excluded from

235 further analyses as they were monomorphic across all samples (MAA122 and MAA140) (Table

236 S2). Another locus (MAA54) was excluded from further analyses as it was functionally

237 monomorphic, in that nearly all individuals were heterozygotes with the same two alleles,

238 suggesting that this primer may amplify two fixed homozygote loci (MAA54 has been shown to

239 amplify two loci in other Artocarpus species) (Wang et al. 2018). Although these three

240 monomorphic loci were excluded from subsequent analyses, the fact that the same loci were

241 found to be polymorphic (with 3 - 18 alleles) in the two closest relatives to $A$. annulatus (Wang

242 et al. 2018, Witherup et al. 2019), suggests that $A$. annulauts is more depauperate in genetic 
243 diversity. Finally, MAA105 was excluded from further analysis due to a null allele frequency

244 value $>0.20$, which can cause significant underestimation of population differentiation (Table

245 S2). This threshold value has been used in other studies to exclude primers that may significantly

246 affect heterozygosity measures (Chapuis and Estoup, 2007; Minn et al., 2014; Muzzalupo et al.,

247 2014). The following loci were included in subsequent genetic diversity and structure analyses:

248 MAA26, MAA156, MAA182, MAA178 A, MAA178 B, MAA196.

\section{Genetic diversity and structure}

250 Analysis of the polymorphic loci with no evidence of null alleles revealed no significant

251 differences in diversity measures across populations (Table 1). The Fixation Index of individuals

252 ( $\left.F_{\mathrm{IS}}\right)$ for all populations was negative (indicating no signs of inbreeding), or in the case of

253 Gunung Mentawa it was barely positive (0.05). The population at Gunung Mentawa had no

254 private alleles, while the other four populations had between one (Gunung Manok) and six

255 (Gunung Bedoh) private alleles. Pairwise comparisons of $F_{S T}$ showed limited levels of genetic

256 differentiation across populations (Table 2). Results of AMOVA among and within populations

257 showed that only $8 \%$ of diversity can be accounted for among populations, and $92 \%$ is within

258 populations (Table 3).

259 All samples were sorted into age classes as described in the methods. Analysis of the six

260 microsatellite loci revealed no significant differences in diversity measures across size classes,

261 except in the case of private alleles; seedlings had significantly fewer private alleles than

262 saplings or mature trees (Table 4). Pairwise comparisons of $F_{S T}$ across tree size class showed no

263 signs of genetic differentiation across size classes (Table 2). Results of AMOVA among and

264 within tree size classes indicated that only $6 \%$ of diversity can be accounted for among

265 populations, and $94 \%$ is within populations (Table 3). 
The first two principle coordinates of the PCoA account for $25 \%$ and $10 \%$, respectively, of 267 the variability in the dataset, and there are no clear clusters based on populations or tree size 268 class (Fig. 3). The population at Gunung Mentawa occupies the smallest space, as does the 269 mature tree size class. STRUCTURE was run on all samples with six loci, and results were 270 analyzed using the Evanno method in Structure Harvester (Earl and vonHoldt 2012) to determine 271 the most probable number of genetic clusters $(K)$. The most likely number was $K=3$. The 272 structure plot shows that the genetic clusters are restricted to neither distinct geographic 273 populations nor size classes of trees, with all three clusters being fairly equally present in each 274 population and each size class (Fig. S1).

\section{Genetic diversity comparisons with closely related species}

276 Expected heterozygosities $\left(H_{\mathrm{e}}\right)$ and inbreeding coefficients $\left(F_{\mathrm{IS}}\right)$, based on the same six 277 microsatellite loci, were calculated for A. annulatus and its closest relatives: A. integer var. 278 integer (cempedak), A. integer var. silvestris (bangkong, a wild relative of cempedak) (Data from 279 Wang et al. 2018), and A. heterophyllus (jackfruit) (Data from Witherup et al. 2019). A one-way 280 ANOVA found no significant difference $(\mathrm{p}=0.113)$ across the species for $H_{\mathrm{e}}$, though $A$. 281 annulatus tended to have the lowest values (Table 5). A one-way ANOVA did find significant 282 difference $(\mathrm{p}=0.020)$ across species for $F_{\text {IS }}$, and a posthoc Tukey HSD test then found significant differences between $A$. annulatus and the other three taxa (A. heterophyllus, $\mathrm{p}<0.01 ; A$. integer var. integer, $\mathrm{p}=0.013 ;$ A . integer var. silvestris, $\mathrm{p}=0.039)$

\section{Discussion}

287 Genetic diversity of closely related Artocarpus species 
288 Understanding genetic diversity and its spatial and temporal structure within endangered species

289 and populations is important in order to make sound conservation management plans, especially

290 for imperiled species with very restricted habitats. When starting with zero information about the

291 population genetics of a species, assessing standard measures of genetic diversity is important to

292 establish a baseline of information, but it is also valuable to consider those measures in a broader

293 context. Looking at closely related, more common congeners allows for an evolutionary,

294 comparative perspective. For example, Widener and Fant (2018) found higher levels of

295 inbreeding in an endangered edaphic specialist compared to its more common congener. In the

296 case of $A$. annulatus and its closest relatives, when considering measures of diversity $\left(H_{e}\right)$ of its

297 most closely related congeners (A. heterophyllus, A. integer var. integer, and A. integer var.

298 silvestris) using the same six microsatellite markers, A. annulatus tends to have lower measures,

299 but there is no significant difference $(\mathrm{p}=0.597)($ Table 5$)$. We also considered broader

300 comparisons with other long-lived, outcrossing wild trees and closely related domesticates.

301 Miller and Gross (2011) reviewed genetic diversity in perennial crops and their wild relatives

302 and reported that based on neutral codominant markers (SSRs and allozymes) cultivated

303 perennial fruit crops retain on average 95\% (from 65\% - 127\%) of the neutral variation found in

304 wild populations. Cultivated Artocarpus crops had elevated levels of genetic variation compared

305 to the closely related A. annulatus (Table 5). This could be an artifact of smaller sampling size in

306 A. annulatus, or it could reflect loss of diversity due to habitat destruction. Another possible

307 explanation is that the cultivated populations may represent descendants of crosses between

308 geographically and genetically distinct individuals, giving rise to novel diversity. Studies have

309 demonstrated that allelic diversity in small populations are likely to be very low simply by

310 chance (Cole 2003), which may be the case for A. annulatus. 
Despite the lower than expected levels of diversity, A. annulatus does not show signs of

312 inbreeding, as evidenced by the negative value of the $F_{I S}$ compared to its three relatives-

313 displaying $F_{I S}$ values between 0.149 and 0.314 (Table 5). The results might seem counter-

314 intuitive for such small and restricted populations. However, since most of the variation present

315 in A. annulatus is distributed within populations (93\%), and because A. annulatus is a long-lived,

316 likely outcrossing tree (as are other members of the genus), these results are put into perspective.

317 Genetic diversity levels could be remnant from when the population of $A$. annulatus may have

318 been larger and may have had higher levels of diversity, and the remaining individuals still retain

319 this because of their lifespan (Guries and Ledig 1979). Additionally, it is possible that $A$.

320 annulatus shows no signs of inbreeding, because long-lived perennials often exhibit stronger

321 selection than non-perennials against inbred plants. Indeed, most woody perennials exhibit high

322 outcrossing rates to maintain greater levels of diversity (Duminil, Hardy, and Petit 2009).

323 Meanwhile, crops like jackfruit (A. heterophyllus) are under human selection and are frequently

324 vegetatively propagated (i.e. grafting) to maintain desired traits (Witherup et al. 2019).

325 Genetic structure within and across Artocarpus annulatus populations

326 The results of several analyses indicate that there is little to no geographical genetic structure

327 exhibited across the five populations of A. annulatus. Principle Coordinate Analysis and

328 Structure analyses indicate there is no genetic differentiation based on the geography of the

329 populations (Fig. 3, Fig. S1). The results from the AMOVA test revealed that only $8 \%$ of

330 diversity was found among populations (Table 3 ), and the $F_{\text {ST }}$ values demonstrated low genetic

331 differentiation among populations (Table 2). Values below 0.05 are considered to represent very

332 low to no genetic differentiation (Frankham et al. 2002), and the values in this study ranged from

3330.028 to 0.089 . The five populations have an area of occupancy of approximately $32 \mathrm{~km}^{2}$ (Zerega 
334 et al. 2019). Three of the populations (Gunung Gayu, Gunung Mentawa, and Gunung Teng

335 Bukap) are geographically closely clustered, each being ca. $0.3 \mathrm{~km}$ apart. Gunung Manok is the 336 most isolated, situated ca. $6 \mathrm{~km}$ from the cluster; and Gunung Bedoh is in the middle, ca. $3 \mathrm{~km}$

337 away from both Gunung Manok and the cluster of three (Fig. 2). Not surprisingly, Gunung

338 Manok is the most differentiated from the others, being the least differentiated from the closest

339 population (Gunung Bedoh). These results, taken in aggregate, suggest that gene flow has

340 occurred among the populations, but that it may be limited across greater distances. The five $A$.

341 annulatus populations may be part of one largely intermixing population across which genetic

342 material is shared via gene flow or may represent remnants of populations that were once larger

343 and less fragmented. Because it is a long-lived tree, the effects of fragmentation and isolation

344 may be slower manifested in the genetic structure.

345 It is of interest to consider methods of gene flow to understand what might be causing low

346 levels of genetic differentiation across populations in such a dramatic landscape as karst forests,

347 where dispersal ability of inhabitants may be limited (Hughes 2017). The two ways for plants to

348 spread genes across space are via pollen dispersal (pollination) and fruit/seed dispersal. While we

349 know virtually nothing about this in A. annulatus, we can turn to its closest relatives to consider

350 possibilities. Recent work has been conducted on elucidating pollination mechanisms in its two

351 closet relatives, jackfruit (A. heterophyllus) and cempedak (A. integer). Both of these

352 monoecious species (separate male and female inflorescences present on the same individual

353 tree) are thought to be pollinated via a three-way mutualistic relationship between the plant itself,

354 gall midges (genus: Clinodiplosis, Family: Cecidomyiidae, Order: Diptera), and a fungus (yet to

355 be identified, but possibly Genus: Choanephora, Family: Choanephoraceae, Order: Mucorales)

356 that grows on the male inflorescences (Gardner et al. 2018; Sakai 2000). The adult gall midges 
357 are thought to be attracted to the same volatile compounds that are similarly emitted by both

358 male and female inflorescences. The midges feed on the pollen of male flowers, and at the same

359 time a fungus (which does not appear to infest other parts of the tree) gradually grows over the

360 length of the male inflorescence. Gravid female midges lay their eggs on the fungus and the

361 young larvae feed on the liquid exuded by the fungal mycelia. As the midges seek out male

362 inflorescences for feeding and egg-laying, they sometimes mistakenly visit female flowers

363 (which offer no apparent reward for the midges but mimic the scent of the male flowers)

364 (Gardner et al. 2018), and in the process may transfer pollen to effect pollination. Given that its

365 closest relatives are both pollinated by gall midges, it is hypothesized that A. annulatus may

366 share a similar mechanism (Gardner et al. 2018). Gall midges are tiny insects, about $1 \mathrm{~mm}$ in

367 length, and have short lifespans (adults live between a few hours to a few days), so they are

368 likely limited in the distances they can travel to disperse pollen (Gardner et al. 2018; Skuhrava

369 1991). Some of the A. annulatus populations in this study are found within just $0.25 \mathrm{~km}$ of each

370 other, while the most isolated population (Gunung Manok) is about $3 \mathrm{~km}$ to the closet population

371 (Gunung Bedoh) and about $6 \mathrm{~km}$ to the next closet populations. Most of what is known about

372 flight range of members of the gall midge family comes from studies of pests. For example,

373 studies of Hessian flies (Mayetiola destructor, Cecidomyiidae) suggest that they choose when,

374 where, and how far to move based on cues from the environment, and are also affected by wind.

375 They can disperse from a few meters to a few kilometers and exhibit nonrandom movement

376 directed by things like scents or certain wavelengths of color (Harris and Rose 1990, Withers et

377 al. 1997, Anderson et al. 2012). Additionally, female midges are more likely to stay in an area

378 where their plant of interest is located as opposed to moving to an area with less attractive plants

379 (Withers and Harris 1996). We still need to learn more about pollination in A. annulatus, but it 
380

381

382

383

384

385

386

387 388

389

390

391

392

393

394

395

396

397

398

399

400

401

seems possible that if it is similar to its closest relatives, gall midges do not typically travel long distances, and the more fragmented A. annulatus populations become over time, the more greatly genetically differentiated they could become. This may explain why the most geographically distant population (Gunung Manok) is also the most genetically differentiated from the others. However, none of the populations are very highly differentiated from one another, and gene flow appears to be occurring (or has recently occurred) among them (Table 2, Fig. S1). This brings us to the other mechanism for gene flow: fruit (i.e. seed) dispersal. The fruits of $A$. annulatus are large (ca. $6 \times 8 \mathrm{~cm}$ ) and distinctive with bumpy or spiky skin and a strong fragrance (Jarrett 1975). Just like its crop relatives, jackfruit and cempedak, the fruit structure grows from the trunk of the tree (Fig. 1), but the wild A. annulatus has much smaller and less fleshy fruits than its crop relatives (Jarrett 1975). While research is limited on fruit dispersal in Artocarpus, there are studies that suggest fruits are spread by large mammals, and this may also be the case in $A$. annulatus. In India, the related $A$. chaplasha depends on large mammals such as the Asian elephant (Elephas maximus), domestic cows (Bos primigenius), buffalo (Bubalus bubalis), and rhesus macaques (Macaca mulatta) as seed dispersers (Sekar 2014). The study species, A. annulatus, shares its habitat with a few sizeable mammals, including François's leaf monkey (Trachypithecus francoisi) and the serow (Capricornis sumatraensis) (Kiew et al. 2017). While anecdotal information from fieldwork suggests that many of the seeds simply germinate under the mother tree, where the fruits drop (i.e. numerous saplings were observed growing in clusters beneath mature trees), it is possible that birds or mammals disperse some A. annulatus seeds, accounting for gene flow and low genetic differentiation across sites (Zerega et al. 2019). Future research could focus on better understanding the contributions of these two modes of gene 
402 flow by studying the distribution of genetic structure of seed (maternal chloroplast loci) vs. 403 pollen dispersed alleles.

404 Genetic structure across age classes of Artocarpus annulatus

405 When an endangered species occurs in habitats that are under threat, it is valuable to know if 406 genetic diversity is being lost over time, such that older, mature individuals harbor greater or 407 unique genetic diversity compared to young seedlings and saplings. As the highly specialized 408 karst habitat becomes increasingly smaller and fragmented due to human pressures, it might be 409 expected that the A. annulatus gene pool could be reduced due to random, stochastic loss of 410 individuals, leading to a decreased level of diversity in younger generations and a genetic 411 bottleneck. When $A$. annulatus individuals were analyzed by size class (seedling, sapling, or 412 reproductively mature), diversity measures tended to be lower in seedlings compared to saplings 413 and mature trees. However, only the number of private alleles was significantly less in seedlings 414 (Table 4). Additionally, PCoA clustering analysis shows that the age classes do not cluster 415 separately (Fig. 3), and AMOVA (Table 3) suggests that only 6\% of diversity was found within 416 age classes. This all suggests that there is no genetic differentiation across size classes, but that 417 allelic diversity may be under threat in the youngest generation of plants. To better understand 418 possible temporal changes, it would be useful to look at a much longer trajectory of time and 419 over a larger space. Assessing the genetic diversity of older herbarium specimens would be one 420 way to help determine if diversity has been lost. Unfortunately, there are only nine historical

421 collections known of $A$. annulatus, the oldest only dates back to the 1960 s, and due to its 422 critically endangered status, sampling of herbarium specimens for DNA was not possible.

423 However, the present study provides a baseline estimate of genetic diversity that can be used for 424 comparison of future studies. 


\section{Informing conservation strategies}

426 Understanding $A$. annulatus genetic diversity can inform conservation management, including ex

427 situ conservation. In the case of $A$. annulatus, different populations were not all strongly

428 genetically differentiated from one another, so there may be little justification for collecting

429 germplasm from multiple individuals from all populations for ex situ conservation in local

430 arboreta and conservation collections. Instead, seeds or seedlings from populations with the most

431 individuals or the most accessible population could be targeted for conservation. For in situ

432 conservation efforts, all sites should ideally be protected (Crozier 1997), however, focusing

433 conservation efforts on the largest population would likely yield similar results in terms of

434 conserving the breadth of $A$. annulatus genetic diversity. In many cases, in situ conservation may

435 be the preferred approach. A recent meta-analysis of 32 plant species from various habitats

436 compared how well plants grew in their local habitats versus a foreign transplant site. They

437 found that in over $70 \%$ of the studies the local plants consistently did better in their habitats of

438 origin, further supporting the argument for conservation of karst areas (Leimu et al. 2008).

439 Additionally, the unique karst habitat is difficult to replicate, and due to the economic

440 importance and biodiversity that karsts hold, in situ conservation is especially important as it

441 conserves an entire ecosystem.

442

\section{Conclusions}

444 The threats to limestone karst ecoystems in Southeast Asia are immense, and we still have 445 much to learn about them (Clements et al. 2006, Hughes et al. 2017). Laws to protect karst

446 ecosystems are severely lacking, and policies in place are often not enforced (Clements et al.

447 2006). Unfortunately, the lack of information about the ecosystems and the biodiversity they 
448 house can make it more difficult to justify their conservation. For this reason, it is important to

449 conduct research in these ecosystems, and by combining available data across studies it can help

450 understand patterns and prioritize regions for protection. Artocarpus annulatus is just one of

451 many endemic species in an ecosystem that is as incredibly unique and diverse as it is fragile,

452 and points to the need for protection of the karst forests of Southeast Asia. The health of $A$.

453 annulatus, as a long-lived, fruit-bearing tree, is crucial for the complex web of plants and

454 animals that depend upon it. Finally, given that $A$. annulatus is the closest wild relative of two

455 important fruit tree species, it may be valuable for breeding programs to expand the growing

456 conditions of jackfruit and cempedak to limestone soils.

457

458 Acknowledgements

459 We would like to thank Jeremie Fant, Fabrizio Grassi, and two anonymous reviewers for

460 valuable and insightful comments that improved this manuscript; Lynnaun Johnson for

461 assistance in the lab; Jegong anak Suka and Jugah anak Tagi for assistance in the field; and the

462 following herbaria for access to collections: SAR, KEP, L, K, HUH.

463

464 References

465 Anderson KM, Hillbur Y, Reber J, Hanson B, Ashley RO, Harris MO (2012) Using sex

466 pheromone trapping to explore threats to wheat from Hessian fly (Diptera: Cecidomyiidae)

467 in the Upper Great Plains. J. Econ. Entomol 105: 1988-1997

$468 \quad \underline{\text { https://doi.org/10.1603/EC12011 }}$

469 Beynan PE (2011) Karst Management, pp. 489. Springer. Netherlands. 
470 Brenda RM, Gendang R, Ambun AU (2004) Geology and geochemistry of the limestone in 471 Sarawak. In: Yong HS, Ng FSP and Yen EEL (eds.) Sarawak Bau Limestone Biodiversity. 472 Sarawak Museum Journal 59, no. 80; Special Issue 6: 41-61

473 Chapuis MP, Estoup A (2007) Microsatellite null alleles and estimation of population 474 differentiation. Molecular Biology and Evolution 24: 621-631 $475 \quad$ https://doi.org/10.1093/molbev/ms1191

476 Chung KF, Leong WC, Rubite RR, Repin R, Kiew R, Liu Y, Peng CI (2014) Phylogenetic 477 analyses of Begonia sect. Coelocentrum and allied limestone species of China shed light on 478 the evolution of Sino-Vietnamese karst flora. Botanical Studies 55: 1

$479 \quad$ https://doi.org/10.1186/1999-3110-55-1

480 Cole CT (2003) Genetic Variation in Rare and Common Plants. Annual Review 34: 213-237. $481 \quad$ https://doi.org/10.1146/annurev.ecolsys.34.030102.151717

482 Clements R, Sodhi NS, Schilthuizen M, Ng PKL (2006) Limestone Karsts of Southeast Asia: 483 Imperiled Arks of Biodiversity. BioScience 56 (9): 733-742 https://doi.org/10.1641/0006$484 \quad \underline{3568(2006) 56[733: L K O S A I] 2.0 . C O ; 2}$

485 Clements R, Ng PK, Lu XX, Ambu S, Schilthuizen M, Bradshaw CJ (2008) Using

486 biogeographical patterns of endemic land snails to improve conservation planning for 487 limestone karsts. Biological Conservation 141:2751-2764

$488 \quad$ https://doi.org/10.1016/j.biocon.2008.08.011

489 Cranbrook EO (2004) A history of animal diversity of the Bau Limestone Area. Sarawak Bau 490 limestone biodiversity. The Sarawak Museum Journal 80(6): 193-220 
491 Crozier RH (1997) Preserving the Information Content of Species: Genetic Diversity,

492 Phylogeny, and Conservation Worth. Annual Review of Ecology and Systematics 28: 243-

$493 \quad 268$ https://doi.org/10.1146/annurev.ecolsys.28.1.243

494 Day M, Urich P (2000) An assessment of protected karst landscapes in South- east Asia. Cave

$495 \quad$ Karst Sci 27(2):61-70

496 Doyle J, Doyle JL (1987) Genomic plant DNA preparation from fresh tissue-CTAB method.

497 Phytochemical Bulletin 19: 11-15

498 Duminil J, Hardy OJ, Petit RJ (2009) Plant traits correlated with generation time directly affect

499 inbreeding depression and mating system and indirectly genetic structure. BMC

$500 \quad$ Evolutionary Biology https://doi.org/10.1186/1471-2148-9-177

501 Earl DA, vonHoldt BM (2012) STRUCTURE Harvester: a website and program for visualizing

502 STRUCTURE output and implementing the Evanno method. Conservation Genetics

$503 \quad$ Resources vol 4 (2): 359-361 https://doi.org/10.1007/s12686-011-9548-7

504 Evanno G, Regnaut S, Goudet J (2005) Detecting the number of clusters of individuals using the

505 software STRUCTURE: a simulation study. Molecular Ecology 8: 2611-2620

$506 \quad \underline{\text { https://doi.org/10.1111/j.1365-294X.2005.02553.x }}$

507 Farjon A, Nguyen TH, Harder DK, Phan KL, Averyanov LV (2002) A new genus and species in

508 Cupressaceae (Coniferales) from northern Vietnam, Xanthocyparis vietnamensis. Novon 12:

$509 \quad 179-189$

510 Ford-Lloyd BV, Schmidt M, Armstrong SJ, Barazani O, Engels J, Hadas R, Hammer K, Kell SP, 511 Kang D, Khoshbakht K, Li Y, Long C, Lu BR, Ma K, Nguyen VT, Qiu L, Ge S, Wei W, 512 Zhang Z, Maxted N (2011) Crop Wild Relatives_-Undervalued, Underutilized and under 513 Threat? BioScience 61 (11): 559-565 https://doi.org/10.1525/bio.2011.61.7.10 
514 Frankham R, Ballou JD, Briscoe DA (2002) Introduction to Conservation Genetics. Cambridge 515 University Press, Cambridge

516 Gao Y, Bin A, Kong H, Kang M, Huang H (2015) Geographical pattern of isolation and 517 diversification in karst habitat islands: a case study in the Primulina 23burnean complex. 518 Journal of Biogeography 42 (11): 2131-2144 doi: $\underline{10.1111 / \text { eva.12495 }}$

519 Gardner EM, Gagné RJ, Kendra PE, Montgomery WS, Raguso RA, McNeil TT, Zerega NJC 520 (2018) A Flower in Fruit's Clothing: Pollination of Jackfruit by a New Species of Gall

521 Midge. Chicago: Int. J. Plant Sci, University of Chicago

522 https://www.journals.uchicago.edu/doi/10.1086/697115

523 Goudet, J (2005) Hierfstat, a package for R to compute and test hierarchical F-statistics. $524 \quad$ Molecular Ecology Notes 5: 184-186.

525 Guries RP, Ledig FT (1979) Genetic Structure of Populations and Differentiation in Forest 526 Trees. Proceedings of the Symposium on Isozymes of North American Forest Trees and $527 \quad$ Forest Insects, p. 42.

528 Harris MO, Rose S (1990) Chemical, color, and tactile cues influencing oviposition behavior of 529 the Hessian fly (Diptera, Cecidomyiidae). Environ. Entomol.19: 303-308 $530 \quad$ https://doi.org/10.1093/ee/19.2.303

531 Hughes AC (2017) Understanding the drivers of Southeast Asian biodiversity loss. Ecosphere 8: $532 \quad 1$

533 Jarrett FM (1975) Four New Artocarpus Species From Indo-Malesia (Moraceae). Blumea 22: 409-410 
535 Jones AMP, Ragone D, Tavana NG, Bernotas DW, Murch SJ (2011) Beyond the Bounty:

536 Breadfruit (Artocarpus altilis) for food security and novel foods in the $21^{\text {st }}$ Century.

537 Ethnobotany Research and Applications.

538 Kiew R, Rafidah AR, Ong PT, Ummul-Nazrah AR (2017). Limestone treasures: Rare plants in 539 Peninsular Malaysia - What they are, where they grow and how to conserve them?

$540 \quad$ Malaysian Naturalist 71: 32-41

541 Kruckeberg AR, Rabinowitz D (1985) Biological aspects of endemism in higher plants. Annual

542 Review of Ecology and Systematics 16: 447-479

$543 \quad$ https://doi.org/10.1146/annurev.es.16.110185.002311

544 Latinne AS, Waengsothorn VH, Michaux JR (2011) Evidence of complex phylogeographic

545 structure for the threatened rodent Leopoldamys neilli, in Southeast Asia. Conservation

$546 \quad$ Genetics 12: 1495-1511 https://doi.org/10.1007/s10592-011-0248-3

547 Leimu R, Mutikainen P, Koricheva J, Fischer M (2006) How general are positive relationships

548 between plant population size, fitness and genetic variation? Journal of Ecology 94: 942-952

$549 \quad \underline{10.1111 / j .1365-2745.2006 .01150 . x}$

550 Lim M Y L (2008). Diversity of limestone orchids in Central and Northern Padawan, Kuching, $551 \quad$ Sarawak. MSc. Diss., Universiti Putra Malaysia

552 Lobell DB, Burke MB, Tebaldi C, Mastrandrea MD, Falcon WP, Naylor RL (2008) Prioritizing

553 Climate Change Adaptation Needs for Food Security in 2030. Science 319 no. 5863: 607$554 \quad 610$ DOI: $10.1126 /$ science.1152339

555 Melhem, T. 2015. Origin and diversity of jackfruit (Artocarpus heterophyllus, Moraceae). M.Sc.

556 thesis, Northwestern University, Evanston, IL, USA. 
557 Miller A, Gross BL (2011) From forest to field: Perennial fruit crop domestication. American

$558 \quad$ Journal of Botany 98 (9): 1389-414 doi: 10.3732/ajb.1000522

559 Münzbergová Z (2005) Determinants of Species Rarity: Population Growth Rates of Species

560 Sharing the Same Habitat. American Journal of Botany 92: 1887-1994 doi:

$561 \quad 10.3732 /$ ajb.92.12.1987

562 Musser GG, Smith AL, Robinson MF, Lunde DP. 2005. Description of a new genus and species

563 of rodent (Murinae, Muridae, Rodentia) from the Khammouan Limestone National

564 Biodiversity Conservation Area in Lao PDR. American Museum Novitates 497: 1-31

$565 \quad$ http://digitallibrary.amnh.org/handle/2246/5666

566 Nielsen SV, Oliver PM. 2017 Morphological and genetic evidence for a new karst specialist

567 lizard from New Guinea (Cyrtodactylus: Gekkonidae). R. Soc. Open sci. 4: 170781

568 https://doi.org/10.1098/rsos.170781

569 Peakall R, Smouse PE (2012) GenAlEx 6.5: Genetic Analysis in Excel. Population Genetic

570 Software for Teaching and Research—An Update. Bioinformatics 28: 2537-2539

$571 \quad$ https://doi.org/10.1093/bioinformatics/bts460

572 Pritchard JK, Stephens M, Donnelly P (2000). Inference of population structure using multilocus 573 genotype data. Genetics 155: 945-959

574 Schmid RB, Knutson A, Giles KL, McCornack BP (2018) Hessian Fly (Diptera: Cecidomyiidae)

575 Biology and Management in Wheat. Journal of Integrated Pest Management 9 (1): 14

$576 \quad$ https://doi.org/10.1093/jipm/pmy008

577 Sakai S, Kato M, Nagamasu H (2000) Artocarpus (Moraceae)-gall midge pollination mutualism

578 mediated by a male- flower parasitic fungus. American Journal of Botany 87 (3): 440-445

$579 \quad$ https://doi.org/10.2307/2656640 
580 Schilthuizen M (2004) Land snail conservation in Borneo: Limestone outcrops act as arks.

581 Journal of Conchology Special Publication 3: 149-154 https://doi.org/10.1641/0006-

$582 \quad 3568(2006) 56[733:$ LKOSAI $] 2.0 . \mathrm{CO} ; 2$

583 Sekar N (2014) Asian elephants are essential as seed dispersers in a disturbed tropical forest.

584 Dissertation, Princeton University

585 Skuhrava M (1991) Gall Midges (Diptera: Cecidomyiidae) in forest ecosystems. In Baranchikov, 586 Yuri N.; Mattson, William J.; Hain, Fred P.; Payne, Thomas L., eds. Forest Insect Guilds:

587 Patterns of Interaction with Host Trees; pp 293-297. Invited keynote 1989 August 13-17;

588 U.S. Department of Agriculture, Forest Service, Northeastern Forest Experiment Station.

589 Struebig MJ, Kingston T, Zubaid A, LeComber SC, Mohd-Adnan A, Turner A, Rossiter SJ

590 (2009) Conservation importance of limestone karst outcrops for Palaeotropical bats in a

591 fragmented landscape. Biological Conservation 142: 2089-2096

$592 \quad$ https://doi.org/10.1016/j.biocon.2009.04.005

593 Tuyet D (2001) Characteristics of karst ecosystems of Vietnam and their vulnerability to human

594 impact. Acta Geologica Sinica 75: 325-329 https://doi.org/10.1111/j.1755-

$595 \quad \underline{6724.2001 . t b 00539 . x}$

596 Van Oosterhout C, Hutchinson WF, Wills D, Shipley PS (2004) Microchecker: software for

597 identifying and correcting genotyping errors in microsatellite data. Molecular Ecology 4 (3):

$598 \quad 535-538$ https://doi.org/10.1111/j.1471-8286.2004.00684.x

599 Wang MMH, Gardner EM, Chung RCK, Chew MY, Milan AR, Pereira JT, Zerega NJC (2018)

600 Diversity and origins of an underutilized tropical fruit tree, cempedak (Artocarpus integer,

601 Moraceae), and its wild relative bangkong (Artocarpus integer var. silvestris). American

602 Journal of Botany: 898-914 https://doi.org/10.1002/ajb2.1094 
603 Wickham H (2016) ggplot2. Elegant Graphics for Data Analysis. Springer-Verlag New York

604 Widener L, Fant JB (2018) Genetic differentiation and diversity of two sympatric subspecies of

605 Castilleja affinis; a comparison between the endangered serpentine endemic (spp. Neglecta)

606 and its widespread congener (ssp. affinis). Conservation Genetics 19 (2) 365-381

607 https://doi.org/10.1007/s10592-017-1009-8

608 Williams EW, Gardner EM, Harris R 3 ${ }^{\text {rd }}$, Chaveerach A, Pereira JT, Zerega NJ (2017) Out of

609 Borneo: biogeography, phylogeny and divergence date estimates of Artocarpus (Moraceae).

610 Annals of Botany 119(4):611-627 https://doi.org/10.1093/aob/mcw249

611 Williams P (2008) World Heritage caves and karst: a thematic study. IUCN (International Union

612 for Conservation of Nature) World Heritage Studies Ser. 2, pp. 34.

613 Withers TM, Harris MO (1996) Foraging for oviposition sites in the Hessian fly: random and 614 non-random aspects of movement. Ecol. Entomol. 21: 382-395

615 Withers TM, Harris MO, Madie C (1997) Dispersal of mated female Hessian flies (Diptera:

616 Cecidomyiidae) in field arrays of host and nonhost plants. Environ. Entomol. 26: 1247-

$617 \quad 1257$

618 Witherup CE, Ragone D, Wiesner-Hanks T, Irish B, Scheffler B, Simpson S, Zee F, Zuberi MI, 619 Zerega NJC (2013) Development of Microsatellite Loci in Artocarpus altilis (Moraceae) and 620 Cross-Amplification in Congeneric Species. Applications in Plant Science 1 (7): 1200423 $621 \quad$ http://dx.doi.org/10.3732/apps.1200423

622 Witherup CE, Zuberi MI, Hossain S, Zerega NJC (2019) Genetic Diversity of Bangladeshi 623 Jackfruit (Artocarpus heterophyllus) over Time and Across Seedling Sources. Journal of 624 Economic Botany 73 (2): 233-248 https://doi.org/10.1007/s12231-019-09452-5 
625 Tseng YH, Huang HY, Xu WB, Yang HA, Peng CI, Liu Y, Chung KF (2019) Phylogeography

626 of Begonia luzhaiensis suggests both natural and anthropogenic causes for the marked

627 population genetic structure. Botanical Studies 60: 20 https://doi.org/10.1186/s40529-

$628 \underline{019-0267-9}$

629 Zerega NJC, Nur Supardi MN, Motley TJ (2010) Phylogeny and recircumscription of

630 Artocarpeae (Moraceae) with a focus on Artocarpus. Systematic Botany 35(4): 766-783

631 Zerega N, Gardner E, Wan Zakaria W, Puad ASA (2019) Artocarpus annulatus. The IUCN Red

632 List of Threatened Species https://dx.doi.org/10.2305/IUCN.UK.2019-

$633 \quad$ 2.RLTS.T86528602A86528612.en 


\section{Figure 1}

Artocarpus annulatus

a) Karst limestone habitat in Kuching Division, Sarawak, b) Roots growing on limestone outcrops, c) White exudate found throughout trees, d) Tree, e) Cauliflorous syncarp (multiple fruit structure), f) Close up of syncarp, and g) Male inflorescence with annulate rings. Photo credits: Nyree Zerega (a-c), Michael Lo ( $d$ and g) and Benedikt Kuhnhäuser (e and f)

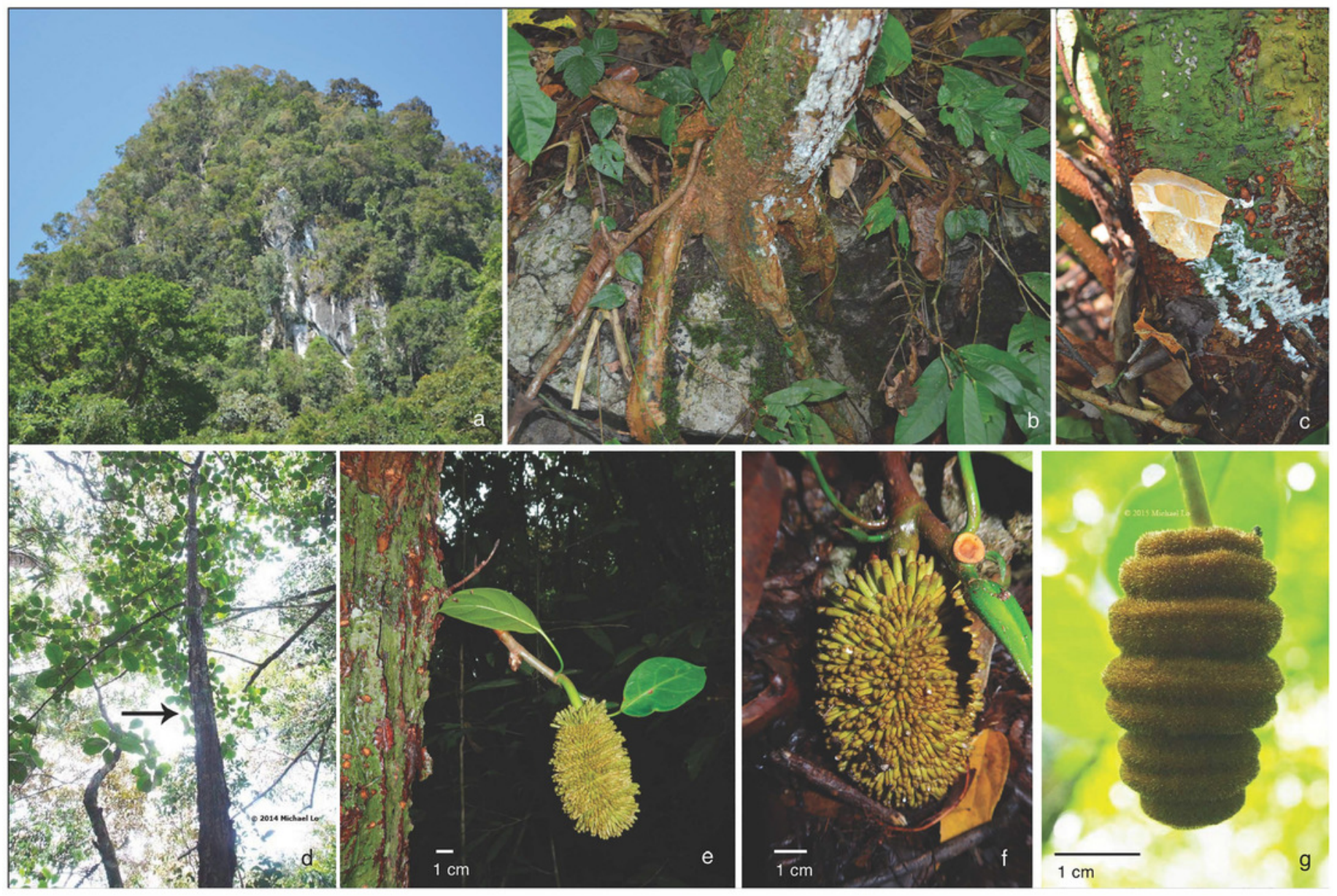




\section{Figure 2}

Artocarpus annulatus distribution

a) Malaysia is shown in dark gray; the area in Sarawak where $A$. annulatus populations are found is indicated by the white box, b) Close up of boxed area from above panel shows extant populations of $A$. annulatus (circles), locations of historical specimens (triangles), and locations that were searched in 2016 and no A. annulatus were found (squares), c) Close up of boxed area from above panel shows known extant $A$. annulatus populations that were sampled in this study. Map Credit: SimpleMappr (2019), CC 0. 


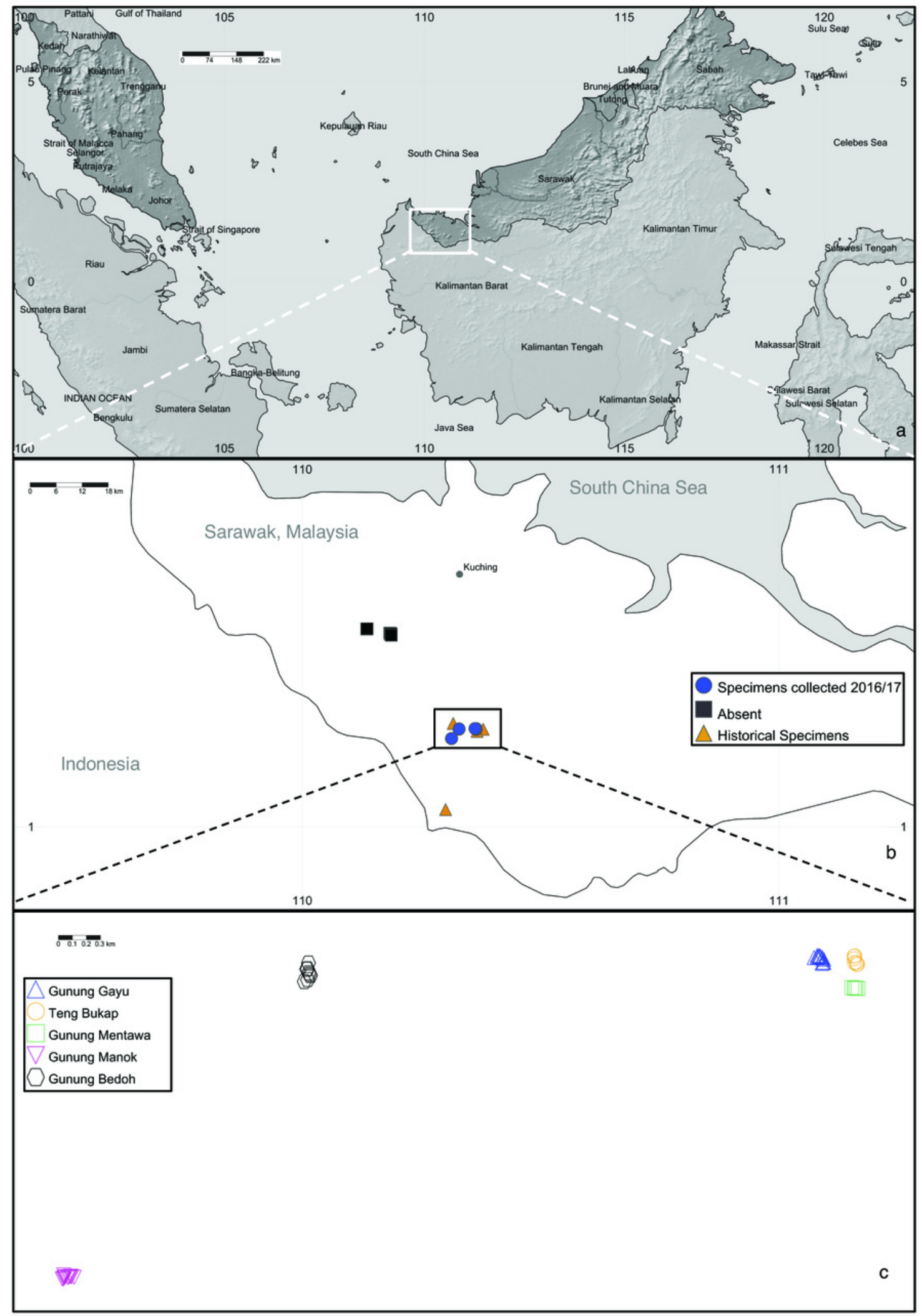


Figure 3

Principle Coordinate Analysis of five $A$. annulatus populations

a) Populations are displayed in different colors, tree size class is represented by different shapes, 95\% confidence ellipses are drawn around populations; b) Tree size classes are displayed in different colors; populations are represented by different shapes; $95 \%$ confidence ellipses are drawn around tree size classes.
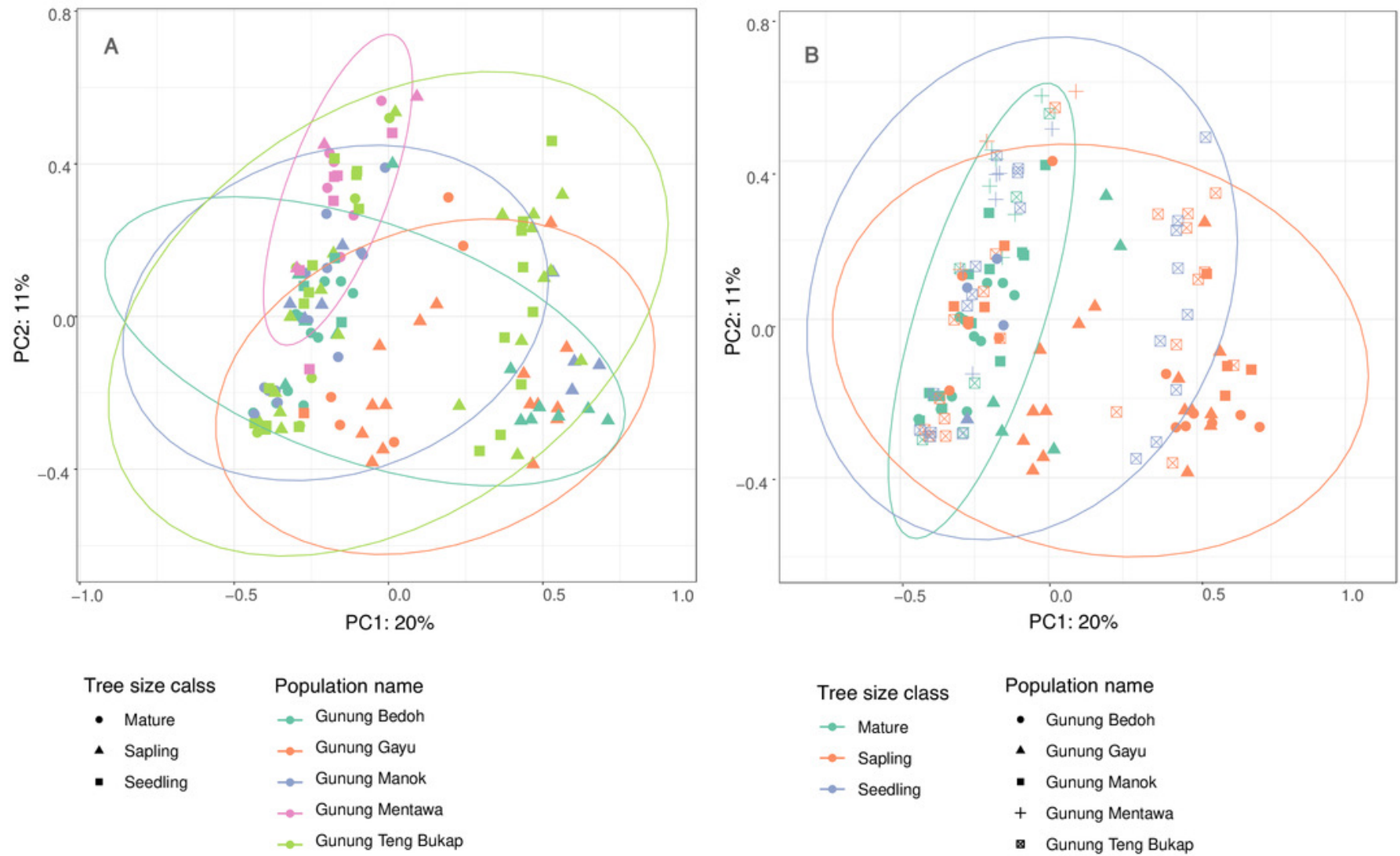


\section{Table $\mathbf{1}$ (on next page)}

Genetic diversity measures of $A$. annulatus populations.

Number of individuals sampled in each population by size class. Numbers in parentheses after population names refer to number of individuals from each size class (mat = mature, sap = sapling, sdlg = seedling). 


\begin{tabular}{llllllllll}
\hline Population & $\mathbf{N}$ & $\mathbf{N}_{\mathbf{a}}$ & $\mathbf{N}_{\mathbf{e}}$ & $\mathbf{A}_{\mathbf{R}}$ & $\boldsymbol{H}_{\mathbf{0}}$ & $\boldsymbol{H}_{\mathbf{e}}$ & $\boldsymbol{F}_{\boldsymbol{I S}}$ & $\mathbf{I}$ & $\mathbf{P}_{\mathbf{a}}$ \\
\hline Gunung Gayu (5 mat, 16 sap, 1 sdlg) & 22 & 3.33 & 2.01 & 3.44 & 0.60 & 0.49 & -0.23 & 0.85 & 5 \\
Gunung Bedoh (11 mat, 12 sap, 3sdlg) & 26 & 3.83 & 1.81 & 3.14 & 0.49 & 0.41 & -0.20 & 0.72 & 6 \\
Gunung Manok (13 mat, 18 sap) & 21 & 2.00 & 1.50 & 2.53 & 0.42 & 0.29 & -0.36 & 0.45 & 1 \\
Gunung Mentawa (6 mat, 3 sap, 6sdlg) & 15 & 2.17 & 1.56 & 2.96 & 0.31 & 0.29 & 0.05 & 0.48 & 0 \\
Gunung Teng Bukap (6 mat, 20 sap, 21sdlg) & 47 & 3.00 & 1.71 & 3.08 & 0.38 & 0.35 & -0.06 & 0.63 & 3 \\
\hline Total (41 mat, 59, sap, 31 sdlg) & 131 & & & & & & & & \\
\hline P value & NA & 0.07 & 0.31 & 0.18 & 0.46 & 0.40 & 0.40 & 0.26 & 0.20 \\
\hline
\end{tabular}

$4 \mathrm{~N}_{\mathrm{a}}=$ no. of different alleles, $\mathrm{N}_{\mathrm{e}}=$ no. of effective alleles, $\mathrm{A}_{\mathrm{R}}=$ allelic richness, $H_{o}=$ observed heterozygosity, $H_{e}=$ 5 expected heterozygosity, $F_{I S}=$ Fixation Index, $\mathrm{P}_{\mathrm{a}}=$ number of private alleles, I = Shannon's Informational Index 
Table 2 (on next page)

Pairwise comparisons of $F_{\mathrm{ST}}$ values

Comparison of $A$. annulatus by population and tree size. 
1

2

Pairwise $F_{\mathrm{ST}}$ Comparison by Populations

\begin{tabular}{llllll}
\hline $\begin{array}{l}\text { Gunung Gayu } \\
\text { (Pop. 1) }\end{array}$ & $\begin{array}{l}\text { Gunung Bedoh } \\
\text { (Pop. 2) }\end{array}$ & $\begin{array}{l}\text { Gunung Manok } \\
\text { (Pop. 3) }\end{array}$ & $\begin{array}{l}\text { Gunung Mentawa } \\
\text { (Pop. 4) }\end{array}$ & $\begin{array}{l}\text { Gunung Teng } \\
\text { Bukap (Pop. 5) }\end{array}$ \\
\hline 0.00 & - & - & - & - & 1 \\
0.067 & 0.000 & - & - & - & 2 \\
0.118 & 0.032 & 0.000 & - & - & 3 \\
0.101 & 0.052 & 0.068 & 0.000 & - & 4 \\
0.061 & 0.032 & 0.059 & 0.028 & 0.000 & 5 \\
\hline
\end{tabular}

Pairwise $\boldsymbol{F}_{\mathrm{ST}}$ Comparison by Tree Size

\begin{tabular}{llll}
\hline Sapling & Seedling & Mature & \\
\hline 0.00 & - & - & Sapling \\
0.021 & 0.000 & - & Seedlling \\
0.020 & 0.014 & 0.000 & Mature \\
\hline
\end{tabular}

3

4 


\section{Table 3(on next page)}

\section{AMOVA}

Results are shown among and within five $A$. annulatus populations, and among and within tree size classes across all five populations. 
1

2

\begin{tabular}{llllll}
\hline \multicolumn{7}{c}{ AMOVA across five populations } \\
\hline Source & $\mathrm{df}$ & SS & MS & Est. Var. & $\%$ \\
\hline Among populations & 4 & 42.80 & 10.70 & 0.17 & 8 \\
Within populations & 257 & 534.27 & 2.08 & 2.08 & 92 \\
Total & 261 & 577.07 & - & 2.25 & 100 \\
\hline \multicolumn{7}{c}{ AMOVA across three tree size classes } \\
\hline Among populations & 2 & 28.15 & 14.08 & 0.14 & 6 \\
Within populations & 259 & 548.92 & 2.12 & 2.12 & 94 \\
Total & 261 & 577.07 & & 2.26 & 100 \\
\hline
\end{tabular}

$3 \overline{\mathrm{df}}=$ degrees of freedom, $\mathrm{SS}=$ sum of squares, $\mathrm{MS}=$ mean square, Est. Var. = estimated variance 4

5 


\section{Table 4 (on next page)}

Genetic diversity measures by tree size class of $A$. annulatus across five populations.

Total values are listed for sample size $(\mathrm{N})$ and private alleles $\left(\mathrm{P}_{\mathrm{a}}\right)$. Mean values across all loci are listed for all other measures. If $p$-value are $<0.05$, different superscript letters indicate significant difference between groups. 
1

2
3

\begin{tabular}{cccccccccc}
\hline Size Class & $\mathbf{N}$ & $\mathbf{N}_{\mathbf{a}}$ & $\mathbf{N}_{\mathbf{e}}$ & $\mathbf{A}_{\mathbf{R}}$ & $\mathbf{H}_{\mathbf{0}}$ & $\mathbf{H}_{\mathbf{e}}$ & $\mathbf{F}_{\text {is }}$ & $\mathbf{I}$ & $\mathbf{P}_{\mathbf{a}}$ \\
\hline Seedling & 28 & 3.00 & 1.77 & 3.46 & 0.41 & 0.36 & -0.16 & 0.65 & $0^{\mathrm{a}}$ \\
Sapling & 46 & 4.33 & 1.80 & 4.02 & 0.45 & 0.42 & -0.06 & 0.77 & $8^{\mathrm{b}}$ \\
Mature & 37 & 4.00 & 1.73 & 3.30 & 0.43 & 0.39 & -0.10 & 0.70 & $6^{\mathrm{b}}$ \\
P value & NA & 0.26 & 0.97 & 0.12 & 0.95 & 0.89 & 0.79 & 0.84 & $\mathbf{0 . 0 3}$
\end{tabular}

$4 \mathrm{~N}_{\mathrm{a}}=$ no. of different alleles, $\mathrm{N}_{\mathrm{e}}=$ no. of effective alleles, $\mathrm{A}_{\mathrm{R}}=$ allelic richness, $\mathrm{H}_{\mathrm{o}}=$ observed heterozygosity, $\mathrm{H}_{\mathrm{e}}=$ 5 expected heterozygosity, $\mathrm{F}_{\mathrm{is}}=$ Fixation Index, $\mathrm{P}_{\mathrm{a}}=$ number of private alleles, $\mathrm{I}=$ Shannon's Informational Index

6 


\section{Table 5 (on next page)}

Comparison of genetic diversity $\left(H_{\mathrm{e}}\right)$.

Comparisons are shown between $A$. annulatus and its closest relatives, $A$. heterophyllus (jackfruit) and $A$. integer (cempedak) based on the same microsatellite loci. There is no significant difference between species for $H_{\mathrm{e}}$, but there is for $F_{I S}$ (indicated by superscript letters). 
1

\begin{tabular}{|c|c|c|c|c|c|c|c|c|}
\hline \multirow[t]{2}{*}{ Locus } & \multicolumn{2}{|c|}{$\begin{array}{l}\text { A. heterophyllus } \\
(\mathrm{N}=746)\end{array}$} & \multicolumn{2}{|c|}{$\begin{array}{c}\text { A. integer var. } \\
\text { integer }(\mathrm{N}=344)\end{array}$} & \multicolumn{2}{|c|}{$\begin{array}{c}\text { A. integer var. } \\
\text { silvestris }(\mathrm{N}=187)\end{array}$} & \multicolumn{2}{|c|}{$\begin{array}{l}\text { A. annulatus } \\
(\mathrm{N}=131)\end{array}$} \\
\hline & $H_{\mathrm{e}}$ & $F_{\mathrm{IS}}$ & $H_{\mathrm{e}}$ & $F_{I S}$ & $H_{\mathrm{e}}$ & $F_{I S}$ & $H_{\mathrm{e}}$ & $F_{I S}$ \\
\hline MAA26 & 0.774 & 0.106 & 0.348 & 0.341 & 0.480 & 0.154 & 0.427 & -0.094 \\
\hline MAA156 & 0.373 & -0.084 & 0.566 & 0.016 & 0.613 & -0.088 & 0.287 & -0.429 \\
\hline MAA182 & 0.554 & 0.223 & 0.178 & 0.360 & 0.594 & 0.182 & 0.087 & -0.146 \\
\hline MAA178A & 0.580 & 0.638 & 0.610 & 0.092 & 0.553 & 0.261 & 0.484 & 0.091 \\
\hline MAA178B & 0.776 & 0.391 & 0.558 & 0.255 & 0.870 & 0.207 & 0.535 & -0.105 \\
\hline MAA196 & 0.730 & 0.609 & 0.599 & 0.165 & 0.521 & 0.179 & 0.497 & -0.439 \\
\hline Mean & 0.631 & $0.314^{\mathrm{a}}$ & 0.477 & $0.205^{\mathrm{a}}$ & 0.605 & $0.149^{\mathrm{a}}$ & 0.386 & $-0.184^{b}$ \\
\hline
\end{tabular}

2 